Oliveira, Jane Soute de. 1991. Desigualdades Sociais no Rio: A Violência Quotidiana. Rio De Todas as Crises. Série Estudos 81:4-16.

Pakulski, Jan, and Waters, Malcolm. 2001. The Death of Class. In Social Stratification in Sociological Perspective. D.B. Grusky, ed. Pp. 866-873. Oxford: Westview Press.

Perelman, Mariano D. 2007. Theorizing Unemployment: Toward an Argentine Anthropology of Work. Anthropology of Work Review 28(1):8-13.

Polanyi, Karl. 2001 [1944]. The Great Transformation: The Political and Economic Origins of our Time. Boston: Beacon Press.
Seligmann, Linda J. 1989. To Be in Between: The Cholas as Market Women. Comparative Studies in Society and History 31(4):694-721.

Thompson, E.P. 1967. Time, Work-Discipline, and Industrial Capitalism. Past and Present 38:56-97.

Wacquant, Loïc. 1989. The Ghetto, the State, and the New Capitalist Economy. Dissent (Fall) 36:508-520.

2002. Scrutinizing the Street: Poverty, Morality and the Pitfalls of Urban Ethnography. American Journal of Sociology 107(6):1468-1532.

. 2008. Urban Outcasts: A Comparative Sociology of Advanced Marginality. Cambridge: Polity Press.

\title{
The Pirate Media Economy and the Emergence of Quichua Language Media Spaces in Ecuador
}

\author{
Simeon Floyd, University of Texas at Austin
}

\begin{abstract}
This paper gives an account of the pirate media economy of Ecuador and its role in the emergence of indigenous Quichua-language media spaces, identifying the different parties involved in this economy, discussing their relationship to the parallel "legitimate" media economy, and considering the implications of this informal media market for Quichua linguistic and cultural reproduction. As digital recording and playback technology has become increasingly more affordable and widespread over recent years, black markets have grown up worldwide, based on cheap "illegal" reproduction of commercial media, today sold by informal entrepreneurs in rural markets, shops and street corners around Ecuador. Piggybacking on this pirate infrastructure, Quichua-speaking media producers and consumers have begun to circulate indigenous-language video at an unprecedented rate, helped by small-scale merchants who themselves profit by supplying market demands for positive images of indigenous people. In a context of a national media that has tended to silence indigenous voices rather than amplify them, informal media producers, consumers and vendors are developing relationships that open meaningful media spaces within the particular social, economic and linguistic contexts of Ecuador.

Keywords: pirate media, informal economy, Quichua language, indigenous media, Ecuador, Andes, racism

\section{Introduction: A Media Explosion}

One afternoon in 2005, I arrived at a farm house in the town of Quilapungo in the Cotopaxi highlands in the Ecuadorian Andes, where my compadres Juan Manuel and Delfina welcomed me after nearly a year of absence. Their kids ran in from the fields. "Dividita rikushun," [Let's watch a DVD!] said Patricio, the 5-year-old boy. That was
\end{abstract}

when I noticed the new additions to the room: a television and a shiny DVD player placed prominently in a tall wooden case. "Kichwapi churay," [Put on one in Quichua for him] said his father, "Kichwata munanka" [He'll like Quichua]. ${ }^{1}$ Patricio sorted through a stack of pirate DVDs, homemade copies burned on consumer blank media, and put on a video that, unlike any I had seen before, featured singing and speaking in Quichua, the Ecuadorian variety of the Inca imperial Quechua language. The national and international media consumed in Ecuador almost exclusively shows light-skinned people speaking Spanish or English, wearing American-style clothes in an urban, affluent environment, while these videos showed indigenous people in traditional clothing with a backdrop of rural highland landscapes. Unlike documentary-style films about indigenous people, most of these videos were in (sometimes un-subtitled) Quichua, meant primarily for indigenous peoples' intra-group consumption. I asked my compadres where they had bought these discs and they informed me that they are for sale at stalls in the regional markets, at the pirate media outlets that had appeared in recent years as vendors, consumers, and artists opened paths of media diffusion through informal and illicit economies that take advantage of newly accessible digital technologies.

That experience of home consumption (Figure 1) soon sent me on ethnographic shopping trips to pirate DVD stalls from tiny village fairs to enormous city markets to urban DVD shops where I could chose among dozens of Quichualanguage DVDs and talk to the people buying and selling them. A year earlier such a level of video production and circulation had been unheard of, but with the rapid spread of DVD playback devices into the rural Andes, it appeared that an indigenous media production boom had occurred, made possible by the way that informal vendors of pirate media 

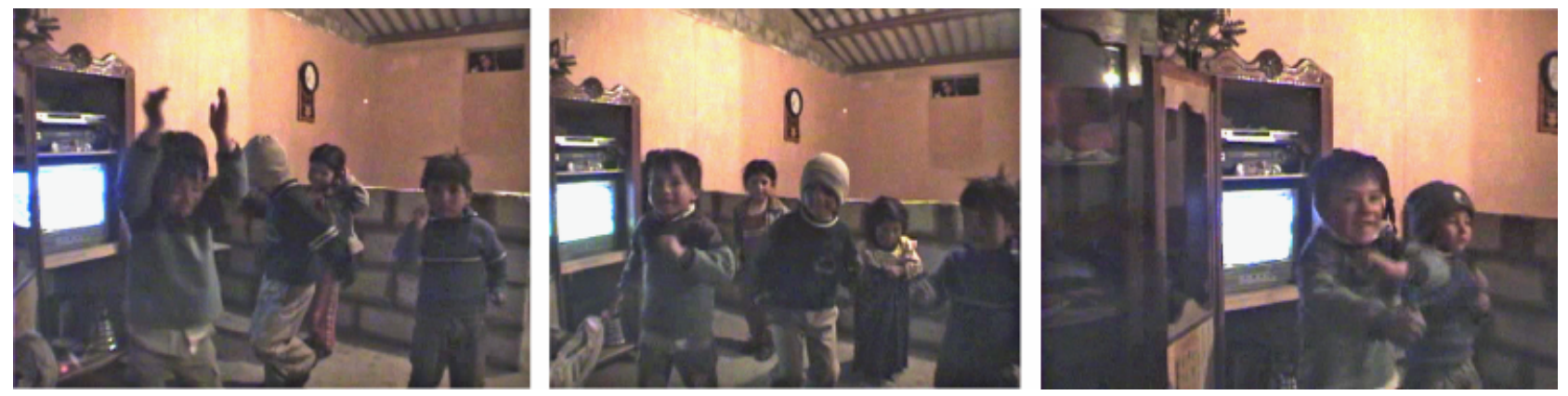

Figure 1. Home consumption of Quichua media: Screen shots of children in Quilapungo singing and dancing along with Quichua DVDs; note TV and DVD player in the case at left.

have responded to indigenous consumption preferences, enabling the circulation of new kinds of cultural representations within these Andean societies. This paper gives an account of the different parties involved in this economy in the context of the parallel "legitimate" media economy in Ecuador, and considers the implications of this media black market for Quichua linguistic and cultural reproduction. Increased circulation of these media forms is basically a by-product of the informal pirate economy, which is in turn a by-product of international mass media industry, and as such this media production has developed organically without any kind of explicit political goals, planning strategies or formal regulatory principals. Within this economy, media producers, consumers, and vendors are developing relationships that open meaningful spaces within the particular social, economic and linguistic contexts of Ecuador.

\section{Background: Race, Language, and Media in Ecuador}

Historically as well as today, Ecuadorian society reflects sharp racial and class inequalities in a system of cultural and political hegemony in which benefits are channeled to a small elite of whites and lighter-skinned people while indigenous people, Afro-Ecuadorians and poor, darker-skinned "mestizos" are kept at a disadvantage. National mythologies have posited social equality based on a supposedly un-differentiated majority of so-called "mestizos," 2 but internal differentiation among "mestizos" also reveals similar racialized social hierarchies (see Stutzman 1981; Weismantel 2001; Whitten 2003; Roitman 2007). Within indigenous societies that are in close contact with non-indigenous or "mestizo" society, the experience of this racialized inequality pressures many indigenous people to approximate features of "mestizo" culture, ${ }^{3}$ notably correlated with widespread language shift to Spanish in many areas (Haboud 1998; Floyd 2004). However, most of these new "mestizos" will not be easily accepted into positions of power, and upper class whites will continue to call them "indios" (Indians) or to refer to them with the insulting term "cholo," pointing out that their phenotype and descent will continue to mark them regardless of whether they call themselves "blanco" (white) or "mestizo." Contrasting with such attempts to hide indigenous roots, prominent displays of indigenous culture and language like those seen in Quichua media work against this process of uneven and unequal assimilation.
Generally speaking, the top rungs of the state and the large businesses are all dominated by urban whites and some upper-class "mestizos," who in turn dominate and define the terms of most sectors of "legitimate" economies; nowhere is this more obvious than in the media. For quick qualitative proof of this situation one could watch the evening news or a telenovela (soap opera), which feature far more European phenotypes than one sees proportionally in any town or on any street corner in Ecuador. To the extent that the mass media industry in Ecuador has been concerned with indigenous people at all, it has been historically geared towards making them into consumers rather than producers, and indigenous people and languages have been excluded from most forms of national media. Quichua language television broadcasts are limited to a half-hour newscast running before dawn and a single verse of the national anthem that plays as the stations sign off around midnight.

Between the extremes of the entrenched dominant media and emerging indigenous media forms there exists a media space sometimes referred to as "popular" media, which basically refers to media produced and consumed by lower class "mestizos." These media enjoy several television broadcast outlets, and share many features with indigenous video, but under the unspoken condition that they do not self-identify as indigenous or use Quichua language. In spite of these denials, however, upper class media consumers are often quick to label this media "Indian," reflecting the "mestizo" -internal hierarchies mentioned above. Yet while there is a kind of covert indigenousness to this media, it has not been able to become a real transformative space for indigenous media because it also internalizes many of the precepts of racialized hierarchy by excluding overt displays of indigenous identity. Quichua video coexists with and sometimes blurs into these media styles while the vendors of pirate media themselves often inhabit the grey area of the "popular," between indigenous and non-indigenous. At the same time, the vendors and other "mestizos" may be heavily invested in differentiating themselves from their indigenous customers. While Quichua media often mixes Spanish with Quichua in creative combinations, "popular" media seldom mixes languages in a reciprocal direction, evidence of the "one-way" direction of this continuum.

My surprise at seeing Patricio playing Quichua language media on his family's home television came in the context of these obstacles in the mainstream media to hear- 


\section{Anthropology of Work Review}

ing indigenous voices, seeing indigenous faces, and addressing themes important to indigenous people. I had long been frustrated by the lack of a media of cultural affirmation for indigenous consumers and had waited for the day that I would see children singing along with Quichua songs as they watch them on television. As I came to grips with what was occurring, I began to see how when the formal or legitimate economy is unable to supply indigenous peoples with a conduit for circulating media amongst themselves the informal economy can step in as a base for the formation of a vibrant parallel media space that subverts the stranglehold of the mainstream media. Indigenous media found an unlikely hero in vendors and reproducers of pirate media who, far from having consciously altruistic motives, are simply tapping into a consumer base and, dollar by dollar, responding to its demand.

\section{Pirate Infrastructure and the "Legitimate" Economy}

The pirate video industry exploded worldwide when heavy and cumbersome poor-quality VHS tapes were replaced by the smaller, lighter, and cheaper loss-free reproduction enabled by digital video discs. Interestingly, informally-produced media made by indigenous people and intended for intra-group media production has been a recent emergent phenomenon in different places around the world (Schein 2002 on Southeast Asia, Larkin 2004 on Africa, etc.). At the level of distributional infrastructure, these indigenous media forms often take advantage of the pirate media black market, hinting at how recent events in Ecuador are part of larger global phenomena. Where legal media markets had offered few possibilities for indigenous media, the black market has offered new accessibility for producers and new affordability for consumers.

In the large urban centers of Ecuador, media piracy is widespread and competes with and undercuts "legitimate" consumption to such an extent that in recent years large international media franchises have been completely put out of business by small-scale entrepreneurs who are able to offer the same products for a fraction of the price (compare pirate DVDs at $\$ 1$ and $\$ 2$ to full-price discs at $\$ 10$ to $\$ 20$ or more). As the availability and affordability of digital media reproduction and playback technologies increased and consumers turned to "illegitimate" digital media from the informal market, franchise stores around Quito like Tower Records and Blockbuster Video closed down one by one while pirate media stalls popped up everywhere, quickly becoming a common feature in the landscape's developing morphology. Even when and where authorized international media distribution infrastructure once existed, it was limited to the more affluent shopping centers in urban areas, and was totally inaccessible to rural and indigenous people. In countries like Ecuador with high populations of impoverished, rural and minority peoples, piracy may be the only reasonable way that media can circulate, either due to prohibitive costs or to the remoteness of the areas consumers live.

Domestic media production in Quichua has been able to grow primarily by piggybacking on the infrastructure of international video piracy. Quichua media is copied, transported and sold by the same people in the same spaces as pirate media, and occupies the same market stalls alongside bootleg Van Damme and Jackie Chan movies. Over the last three or 4 years (2004-2008) cheap models of digital disc players flooded the Ecuadorian market, at first designed for video compact discs (VCDs) and later for higher-quality digital video discs (DVDs). ${ }^{4}$ These media referred to in Ecuadorian Spanish and Quichua by nativized versions of their English names: cidí and dividí. The spread of digital video playback has occurred with unprecedented speed and scale, and today even the most remote mountain and forest indigenous communities usually have at least one DVD player. Since this technology is self-contained and does not depend on broadcast infrastructures, it is currently having an even greater impact in many indigenous communities than radio, network television, or the internet. As vendors scrambled to find niches in this booming market, some have competed by including local offerings like Quichua videos, although Hollywood movies and other international media make up the largest part of the market.

The International Intellectual Property Alliance (IIPA), a coalition of U.S. businesses with the goal of international copyright enforcement, has had Ecuador on its special "watch list" for the last several years (IIPA Reports for Ecuador 2005, 2006, and 2007). The IIPA also claims that piracy "prevents recording companies from investing in local acts and jeopardizes the opportunities that Ecuadorian artists have to develop and promote their talents" (2006:241). Yet unlike international corporate media, domestic music video producers are often happy to see their discs pirated because it works as free publicity for live performances (Domon 2006 attests that this is also true in Vietnam). In Ecuador copied and re-copied pirated videos are low-cost advertising for concerts, where the real money is made. Videos of popular and Quichua-language musical performers frequently feature cellular phone numbers on the screen for contracts for live shows. While upper class viewers joke about this practice and contrast it with highbudget MTV style videos, these media form an important link in a symbiotic economy in which performers use pirate media vendors for advertising while in turn vendors use performers' productions for their technically "illicit" sales. Indigenous consumers use both parties - the performers and the vendors - for access to a cheap source of entertainment and to learn about performers they might like to see in concert, or even to contract for their town fiestas. The frame of thought advanced by organizations like the IIPA appears totally incongruent with the activities going on in households and market stalls around Ecuador.

On my way back from Quito on a recent trip to Quilapungo I jumped off the bus at Pujilí in order to check out the selection at the pirate DVD stalls around the periphery of the Sunday market where (Figure 2) thousands of people milled around buying and selling produce and goods of all kinds. After browsing through the rows of bootleg Hollywood movies, I asked the vendor if he had any Quichua videos. He produced a stack of DVDs including mostly music videos, with a few comedy and drama discs as well as some videos of local religious events such as the annual Niño de Isinche procession, which takes place at a local sacred site and is attended by many indigenous people as well as some "mestizos." A common practice while shopping for bootleg DVDs in Ecuador is to ask the vendor to test them on his or her monitor and playback machine to 


\section{Anthropology of Work Review}

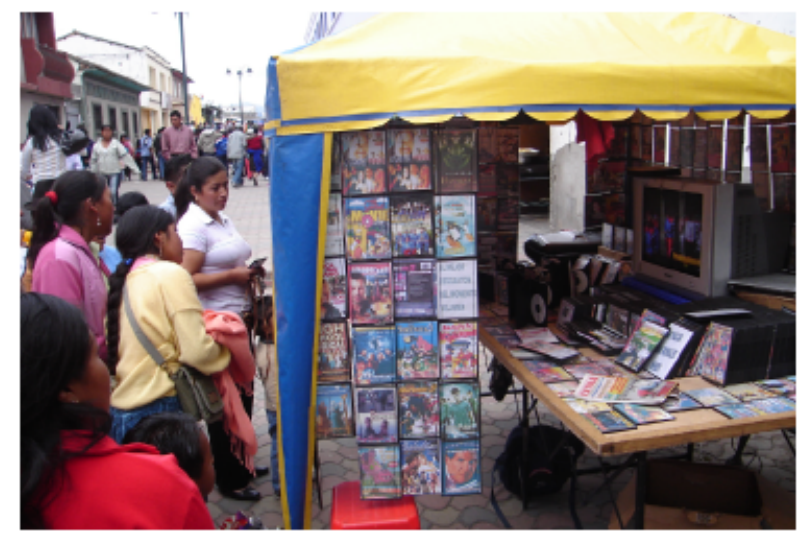

Figure 2. A pirate DVD stall at the Pujilí Sunday market. Indigenous people from around the region come on Sundays to shop.

make sure that they are not flawed. As we watched excerpts from the DVDs a crowd formed around the stall, fascinated by the video; the vendor quickly sold five or six of copies of the same discs that I had picked out. "Look," I said to him in Spanish, "I am helping you advertise. Look at how fast these Quichua DVDs sell." He shrugged off my comment, and clearly separated his own tastes from those of his customers: "Who knows why they like it." I had similar experiences in markets around the Ecuadorian Andes, suggesting to me a desire to form new media spaces for indigenous people is not necessarily a central motivation for many vendors' role in Quichua media circulation.

Salespeople of pirate DVDs appear to have little idea of the new communicative flows they are enabling for Quichua-speakers. In some cases the vendors are Quichuaspeaking indigenous people themselves, while in most cases they are Spanish speakers who could be described as "mestizos" or "mishukuna" in Quichua - although they might be seen as "Indian" to some degree by upper class whites within the frame of internal "mestizo" differentiation described above. These lower class "mestizo" and indigenous salespeople are not necessarily fulfilling a key role in indigenous media circulation out of solidarity with indigenous consumers, but rather have simply found a niche in which they can exploit market demands that the mainstream media ignores. When I asked vendors about the selection of DVDs they offered, from Hollywood and Hong Kong movies to mainstream Latin American productions to homemade indigenous videos, they tended to frame their diverse selection as simply a way to offer variety to consumers. Most of them buy whole collections wholesale from production centers in provincial capitals like Latacunga and Riobamba, and while I was not able to follow the supply chain to this level, it is highly unlikely that many of these wholesalers have legal distribution agreements with the creators of any of the media they reproduce, foreign, or domestic. Interestingly, the same mass copying and uncopyrighted distribution that makes money for vendors simultaneously terrifies the formal economy while allowing the informal economy to flourish. Indigenous people gain access to media, vendors make a living, and corporations and the state are cut out of the flow.
Conspicuously absent from these market relations are the whites and upper classes, since the consumers, producers, and middlemen of the Quichua media economy are indigenous people and lower-class "mestizos." Upper class Ecuadorians consume both "legitimate" and pirate media, but the pirate outlets in their neighborhoods do not stock Quichua videos. Rather, they order foreign media, often in English or European languages without subtitles. Once when conversing with an urban, upper class friend, I mentioned the names of several of the most current and popular Quichua music stars and she said she had not heard of any of them. Whenever I see her she reminds me of how hilarious she found my comment at the time: "I don't know where you shop for DVDs, but if you shopped where I shop you would know who Ángel Guaraca is." This is funny in an upper class context because it plays on the class and race codings of taste and shopping spaces, and highlights the segregated media worlds of Ecuador. In the following section I will conclude by describing some of the interior shape of this newly emerging indigenous media space that, while invisible to elites, is starting to have powerful implications for indigenous cultural practices and discursive possibilities in Quichua.

\section{The Aesthetics of an Underground Indigenous Media Economy}

The emergence of a Quichua media space parallel to and beyond the reach of hegemonic media space is dependent on the operation and development of different "economies" of language and performance, meaning that here linguistic form, performative style and representational communicative practices are the goods that are traded and circulated through the market. ${ }^{5}$ This market inverts non-indigenous Ecuadorian society's devaluation of Quichua discourse by instead giving it a premium. These value systems are the terrain that producers and vendors must negotiate as they endeavor to meet diverse indigenous consumers' media demands.

Circulation of Quichua media moves among all the different Quichua-speaking regional ethnic groups and the Quichua videos found in any one area feature performers from all around the Ecuadorian highland provinces. ${ }^{6}$ Music videos are the most popular items, but I have also encountered feature-length dramatic films and bilingual street comedy routines as well as videos of local festivals, religious processions, traditional dances, and village bullfights. The most notable aspect of the videos is their composition in an indigenous aesthetic framework, meaning that they employ indigenous language (often without subtitles), traditional Andean clothing, scenes of highland landscapes and references to indigenous communities, and themes centering on social issues important for rural Andean people. Indigenous viewers can see people and places they recognize and practices of representation that contrast markedly with the images and discourses seen the mainstream media. Instead of showing a Spanish-speaking white urban context, Quichua media provides a reinforcement of local ways of life, especially important for the consciousness-formation of children and young people.

Compared with high budget MTV-style music videos, popular Ecuadorian music videos are marked by a low 
production value and by their use of local scenery such as parks, plazas, and lookout-points (of which Andean Ecuador has many). A number of singers travel from their home provinces to the Inca ruins of Ingapirca in the province of Cañar to film videos with backdrops of pre-Colombian temples. Quichua videos explicitly reference important local places in their lyrics, like one song that begins "Kultamantami shamuni. Munjasmantami shamuni." [I come from (the town of) Colta, I come from (the town of) Monjas] (Colteñito, Piter Vacacela). Other songs reference the different volcanic and glaciated peaks prominent in the highland imagination (see Lyons 1999): "Chimborazoka chiri chirilla. Tunkurawaka kunuk kunuklla." [Mount Chimborazo is very cold. Mount Tungurahua is very hot] (Erupción Carnaval, Delfín Quishpe). Some mark out time on the ritual calendar, singing about different holy days: "Carnaval puncha chayamushkami. Carnaval puncha tikramushkami." [Carnaval day has arrived here. Carnaval day has returned here] (Erupción Carnaval, Delfín Quishpe). To tie these images and performances together, Quichua videos heavily employ stylistics from the graphic options of consumer video editing software - software that is sometimes sold in pirate copies at the same stalls that sell Quichua DVDs.

Quichua-language media production also reflects global processes that are currently affecting Quichua-speaking communities, specifically the difficult economic situation imposed on Ecuador that has motivated increasing international migration to the United States and Europe (Gioconda et al. 2005, etc.). Cañar and the southern Andes have been the hardest hit areas by outgoing migration (Miles 2004; Ponce Leiva 2005). Included on the Cañari singer Manuelito's video disc is an interview in which he explains why he dedicated one song to migrants and their families:

Chaypi grabarkani ñukanchik como "Me voy a Europa" nishka takiyta. Chay karka, mas que todo ñukanchik mashikuna, ñukanchik allyukuna karu llaktaman rirkakuna. Y chaykunamanta casi tukuy chay, tukuy chay yuyaykunata japishpa, imalayami shukta llakta rinkuna, wawata warmita mamata sakishpa, rinkuna, manachu, shinallata. Kutin kunan karullaktaman kakpika ña warmipish shuktawan asirin, shuktawan tupan, chashna nin. Bueno mana tukuy warmikuna, shinapish maykankuna shina kan. Realidadta nuka rimashpa kashkani pero kaypi ñukanchikka kay videota rurakunchik, shinallata ojala kikinkunaman gustanka, manachu.

[Then we recorded the song called "I'm going to Europe." That was about our friends and family who travel to far away countries. Almost all of them have had that idea, about how to go to another country, leaving behind their children, wives and mother, they go just like that. And once they are in a far away country their women laugh with other men, they meet other men. That is what they say. Well, not all women, but some of them are like that. I needed to talk about reality; but here we made this video, and I hope you all like it.]
For indigenous consumers, it was about time that someone "talk about reality," as Manuelito puts it. Unlike with the national or international media, Quichua viewers can easily make connections between Quichua DVDs and their own experiences, from their pre-Colombian histories to present situations of social inequality (Figure 3). The fact that the demand for Quichua videos is on the increase shows that, given a choice, many Quichua people would rather see someone like themselves on TV, someone who knows and addresses their experiences. For indigenous people in general, and especially for young people, these new media have quickly become a naturalized part of everyday household life. Instead of watching media that stems from precepts of racial and cultural inferiority of indigenous people, viewers have access to culturally affirming media that casts indigenous people in a positive and prominent role. Children may find alternatives for emulation in these media, as in one video clip from my field data shows two boys from the community of Quilapungo singing a song in Quichua (Figure 4). "Maypi shina yacharkanki cantana kankuna?" [Where did you two learn to sing like that?] my voice behind the camera asks them. "CiDipi, nachu?" [From the CD, right?] prompts their mother. "CiDipi uyarkankichik? [You heard it on the CD?] I ask them. "CiDipi atirkani niy." [Say you learned it on the CD] prompts their mother again. The boy replies: "Telepi." [On the television]. This little exchange illustrates some of the ways that families are reproducing and circulating Quichua language content they hear on their televisions.

Quichua creative output can create aesthetic feedback loops, reproducing and circulating representational styles. For example, one friend from the community of Oyacachi requested that I bring my video camera to a waterfall where he posed with his two nieces while playing charango for the camera. Quichua singers often record their videos against scenic Andean backdrops of rushing water, as in the accompanying photo of a singer from Chimborazo and his backup singers (Figure 5).

Once pirate media copiers and vendors distribute Quichua media out into indigenous households, it begins to take on a life of its own as consumers make it part of their consciousness and habits. Consumption of Quichua media may help to stabilize linguistic and cultural practices by encouraging children to develop a sense of a world where indigenous people are protagonists. It alleviates some of the hegemonic weight of the underlying classist and racist messages that have long dominated Ecuadorian media. Its long-term consequences are by no means certain, but as the generation of children that are now being socialized with Quichua DVDs get older, new indigenous media spaces will continue to take shape. The continuation of these processes are contingent on the informal market's continued service to Quichua media space, a factor that may come into dispute as international power brokers attempt to control piracy. $^{7}$

\section{Conclusion: Costs and Benefits of the Informal Market}

In this paper I have tried to trace the connections between indigenous music video producers like Manuelito the Cañari singer, pirate digital media vendors like the man tending his stall at the Pujilí market, and home consumers of 

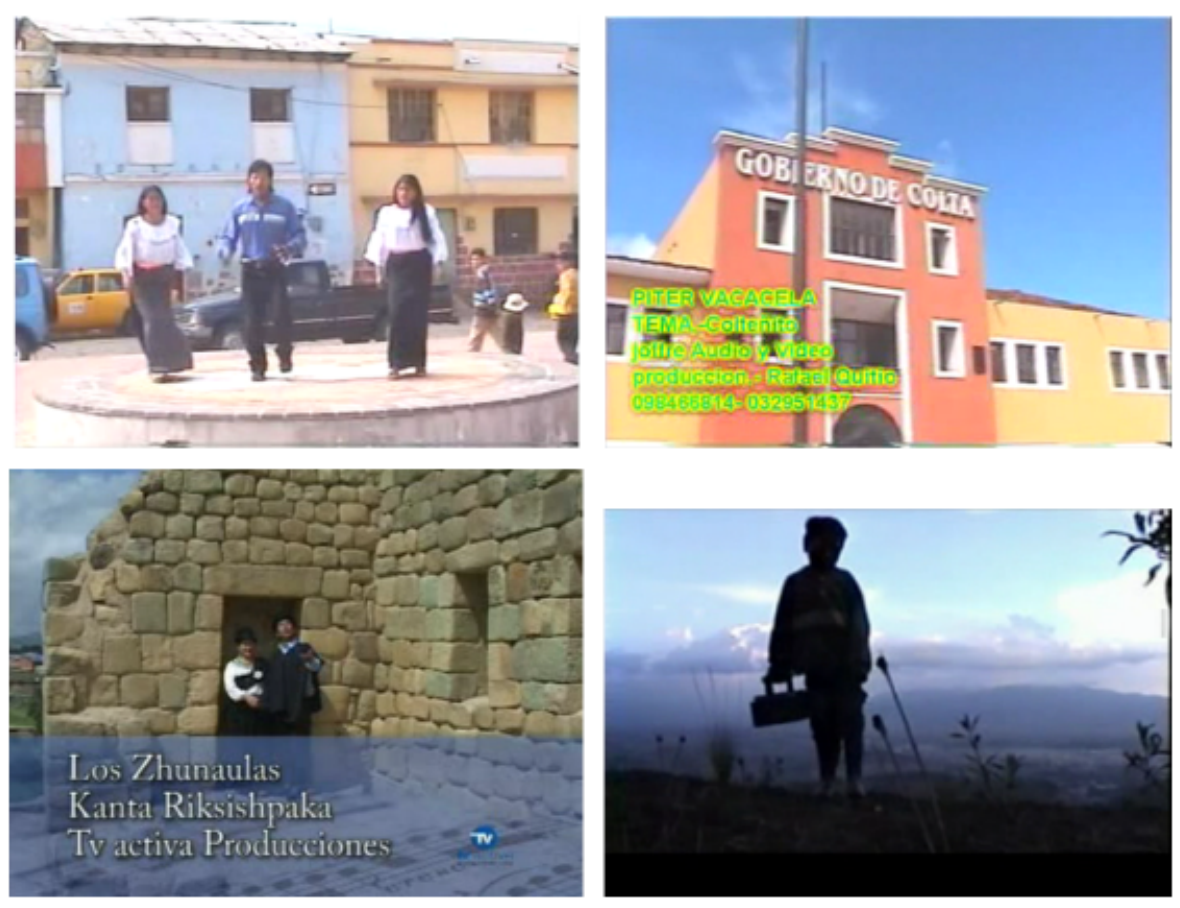

Figure 3. Quichua videos show representations of: indigenous performers in traditional clothing (top left - from Piter Vacacela's Colteñito); local landmarks and performers' contact information (top right - from Piter Vacacela's Colteñito); backdrops of pre-Colombian ruins (bottom left - from Duo los Zhunaulas' Kanta Riksispaka); and stories about labor and international migration (bottom right - from Sinchi Samay Producciones' La Navidad de Pollito).

Quichua media like Patricio in Quilapungo - and to relate the relationships among these parties to mainstream media in Ecuador and the structures of social inequality that it reflects. Once Quichua media enters the cycle of "illicit" reproduction and sales, it begins to circulate beyond the control of its creators, not bringing them direct sales incomes but rather generating recognition among consumers who then may pay for live performances, and indeed, singers and comedians with hit pirate DVDs frequently pack stadiums based on this free advertising. Copiers and ven-

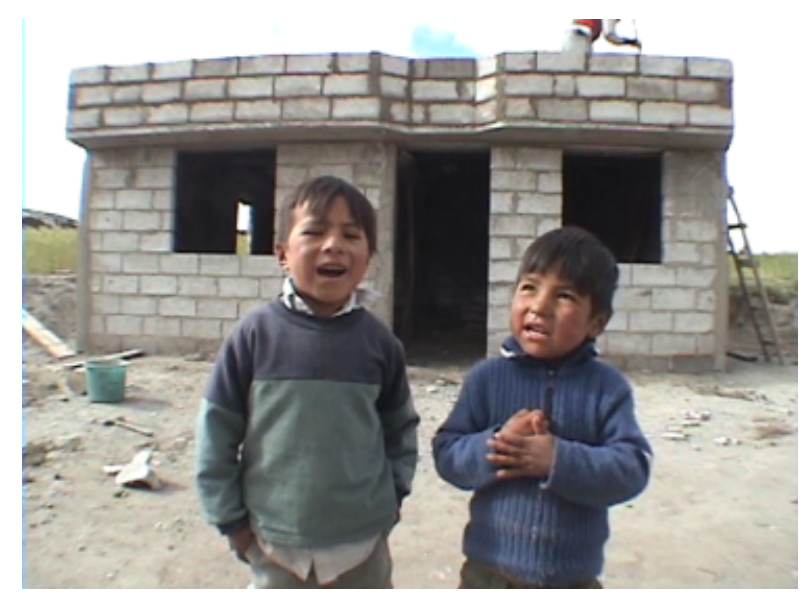

Figure 4. Home consumption and linguistic reproduction: The kids in the Cuchiparte family sing Quichua songs they learned watching DVDs. dors in turn make a modest profit of a few cents over the costs of the blank media, plastic cases, and xeroxed covers of the DVDs they sell, and in many cases act as an unknowing link between producers and consumers of Quichua media. They stock Quichua videos not necessarily as purposeful facilitators of this link, but as a way to respond to the demand of their particular market niches, which is why pirate media outlets in more upscale parts of the cities do not stock Quichua videos but rather respond to that clientele's demands for mainstream media and international specialty items. Vendors catering to indigenous people, however, have located a population of heavy consumers of Quichua media and have stepped in to supply them with it based on a more-or-less unambiguous motive of making money. But since they pay no royalty fees, they can offer this media to indigenous consumers very cheaply, allowing new practices of home media consumption to develop in indigenous households along with this relatively unrestricted media circulation. This phenomenon in turn, as I tried to show in the final section, is creating media feedback loops that help to structure consumers' aesthetic frames, reproducing indigenous cultural representations through emulation and repetition.

The official channels for media circulation remain blocked off for indigenous media in Ecuador, and only the pirate media economy has been able to offer Quichua video a means of circulation. In this sense, indigenous media becomes a kind of contraband, traded on a black market of cultural and linguistic capital, permitted only because it is so widespread that repression would not be practical. Quichua is cornered into the informal section of street cor- 


\section{Anthropology of Work Review}
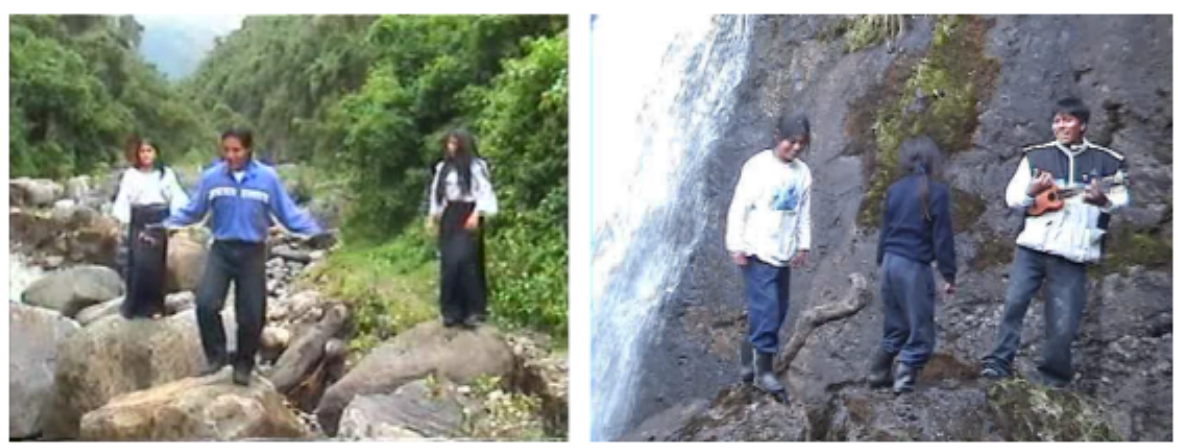

Figure 5. Aesthetic feedback: A homemade video from the community of Oyacachi (right) resembles the compositional styles of Quichua music videos (left, from Curi Sisa by Piter Vacacela), using backdrops of running water and natural surroundings.

ners and rural markets while the mainstream continues to circulate hegemonic racial and cultural representations. This exclusion of indigenous media from the mainstream may have some positive dimensions, however, because the illicit economy offers indigenous media a sheltered space that is hidden from the gaze of the corporate media or the state, and that enjoys some protection from being coopted or bought out. By offering an alternative media economy, Quichua video is an example of indigenous autonomy over both the consumption and the production of media; it already appears to be having more social impact in a couple of years than the limited existing Quichua print media and pedagogical materials have had over the decades that they have existed, perhaps in part because of the way that digital video bypasses the problematics of literacy in indigenous languages (see Romero-Little 2006) and provides an spoken (and gestural) medium for what have traditionally been unwritten languages. Quichua video is providing a forum for reflection on the socioeconomic difficulties faced by indigenous people, and it helps the different Quichua ethnicities to become aware of each other and of shared largerscale features of Andean identity. For indigenous children finding their way through racialized and hierachized topographies in the media and in their daily social interactions, a climate of cultural affirmation is the key to cultural and linguistic transmission, and in this sense new media spaces may prove vital to the continuance of highland Ecuadorian indigenous people as a distinct group.

Under the radar and off the map, the illicit marketplace is allowing Quichua discourse to demarcate its own autonomous media space, when all that the national media ever offered indigenous culture was erasure. Oddly, despite the precepts of capitalist market logic at this moment of its advanced entrenchment, it is the "illicit" entrepreneurs that actually seem to better satisfy and exploit market demands for indigenous media that the official media is uninterested in helping to circulate. Simply by following market flows, pragmatic informal vendors expose this hypocrisy by proving that, given a platform, a Quichua media economy can flourish in a market that is perhaps freer than "free market" advocates have dared to imagine.

\section{Acknowledgments}

First of all, I thank the Cuchiparte family of Quilapungo, Province of Cotopaxi: Juan Manuel, Delfina, and their children; Jorge, Elvira and their children; Taita Juan Manuel and Mama Josefina, and the rest of their children and grandchildren. Thanks also to the Parión family of Oyacachi, especially to Nelson, Dina and Mélida Parión who appear in one still image. Delia Quilumbaquí's help with some of the transcriptions was greatly appreciated. Many thanks also to the Fulbright program, the National Science Foundation, the Endangered Language Fund and the University of Texas for supporting my fieldwork with Quichua-speaking people in Ecuador.

\section{Notes}

1. This is a bit of an understatement, as I had spent a good part of the previous four years researching Quichua language and culture in Quilapungo and other towns around Ecuador.

2. I use the racial/cultural term "mestizo" in quotes in this paper to highlight the internal inequality within this social category that is masked by referring to it as a racially undifferentiated population.

3. One anonymous reviewer of an earlier version of this paper protested that I appeared to be describing all Ecuadorian "mestizos" as racist by pointing out the racism that indigenous people confront in "mestizo" society. However, studies of racism in society are not really concerned with labeling certain individuals or groups as racist, which is usually pointless, but rather with pointing out structural racism at a societal level, which I consider to be one of the main responsibilities of the ethnographer. This is what I am doing here.

4. For convenience in this paper I use the term "DVD" for both types of media.

5. My approach is along the lines of work that connects a Gramscian view of hegemony to the level of linguistic expression and communicative interaction - see Ives (2004). This way of seeing language and performance as central parts of the "economies" of social life has some precedent within the subdiscipline of linguistic anthropology, especially within the framework of the "political economy of language" (for example, Irvine 1989); similar analogies can be found within Marxist semiotics (RossiLandi 1983) as well as in general social theory (i.e. Bourdieu and Thompson 2001, etc.).

6. I have encountered Quichua DVDs from most of the highland provinces including Loja, Cañar, Cotopaxi, and Tungurahua, Imbabura and, especially, Chimborazo, which 
is the production capital. Circulation is also international, as Peruvian and Bolivian Quechua DVDs often turn up as well.

7. As I make final revisions to this paper, copyright laws are being debated at the Ecuadorian Constitutional Assembly. President Correa has suggested a policy that does not demand royalties, but rather taxes blank media and directs some of the tax revenue to artists. This suggestion is in line with other progressive stances made by Correa. With respect to indigenous languages, the proposed new constitution includes an article elevating Quichua to a semi-official level. Correa is also well known for including Quichua translations and even speaking limited Quichua himself at public speeches and on the national television channel (which is often at odds with the corporate media). The current Ecuadorian government may be taking some steps towards a more linguistically inclusive national climate, in contrast to the history of exclusion described in this article, which originates in a previous period of Neoliberal-leaning regimes.

\section{References}

Bourdieu, Pierre, and Thompson, John B. 2001. Language and Symbolic Power. Cambridge: Harvard University Press.

Domon, Koji. 2006. “Unauthorized File-Sharing and Pirated CDs without Effective Copyright Enforcement: A Vietnam Case Study." Electronic document, http:/ / www.serci.org/ documents.html, accessed February 12, 2007.

Floyd, Simeon. 2004. “Speaking Quichua, Speaking Spanish, Speaking Both: an ethnography of bilingual speech in indigenous Ecuador." MA Thesis, Latin American Studies, University of Texas.

Haboud, Marleen. 1998. Quichua y castellano en los Andes Ecuatorianos: los efectos de un contacto prolongado. Quito: Abya Yala.

Herrera, Gioconda, María Cristina, Carrillo, and Alicia, Torres, eds. 2005. La migración ecuatoriana: transnacionalismo, redes e identidades. Quito: IMPREFEPP.

International Intellectual Property Alliance. 2005, 2006, 2007. "Special 301 Report: Ecuador." Electronic document, http://www.iipa.com/countryreports.html, accessed May 30, 2008.

Irvine, Judith.T. 1989. When Talk Isn't Cheap: Language and Political Economy. American Ethnologist 16(2):248-267.
Ives, Peter. 2004. Language and Hegemony in Gramsci. London: Pluto Press.

Larkin, Brian. 2004. Degraded Images, Distorted Sounds: Nigerian Video and the Infrastructure of Piracy. Public Culture 16(2):289-314.

Lyons, Barry. 1999. “Taita Chimborazo and Mama Tungurahua" A Quichua Song, A Fieldwork Story. Anthropology and Humanism 24(1):32-46.

Miles, Ann. 2004. From Cuenca to Queens: An Anthropological Story of Transnational Migration. Austin: University of Texas Press.

Ponce Leiva, Javier, ed. 2005. Migrantes: Problemas y Ayudas. Quito: Editorial El Conejo.

Roitman, Karem. 2007. "Mestizaje and Development in Ecuador: A Study of Guayaquil's and Quito's Upper Classes." PhD Thesis. Oxford University.

Romero-Little, Mary Eunice. 2006. Honoring Our Own: Rethinking Indigenous Languages and Literacy. Anthropology and Education Quarterly 37(4):399-402.

Rossi-Landi, Feruccio. 1983. Language as Work and Trade: A Semiotic Homology for Linguistics and Economics. South Hadley, MA: Bergin and Garvey.

Schein, Louisa. 2002. Mapping Hmong Media in Diasporic Space. In Media Worlds: Anthropology on New Terrain. Faye Ginsburg, Lila Abu-Lughod, and Brian Larkin, eds. Pp. 229-246. Berkley: University of California Press.

Stutzman, Ronald. 1981. El Mestizaje: An All-Inclusive Ideology of Exclusion. In Cultural Transformations and Ethnicity in Modern Ecuador. Norman. E. Whitten, ed. Pp. 45-94. Urbana: University of Illinois Press.

Weismantel, Mary. 2001. Cholas and Pishtacos: Stories of Race and Class in the Andes. Chicago: University of Chicago Press.

Whitten, Norman. 2003. Symbolic Inversion, the Topology of El Mestizaje, and the Spaces of Las Razas in Ecuador. The Journal of Latin American Anthropology 8(1):52-85. 